1

\title{
REVIEW
}

\section{Pregnancy and lactation, a challenge for the skeleton}

\author{
E M Winter(101, A Ireland ${ }^{2}$, N C Butterfield ${ }^{3}$, M Haffner-Luntzer ${ }^{4}$, M-N Horcajada ${ }^{5}$, A G Veldhuis-Vlug ${ }^{1,6}$, L Oei $^{7,8}$, \\ G Colaianni ${ }^{9}$ and $\mathbf{N}$ Bonnet $^{5}$
}

${ }^{1}$ Leiden University Medical Center, Department of Internal Medicine, Division of Endocrinology, Center for Bone Quality, Leiden University Medical Center, Leiden, the Netherlands

${ }^{2}$ Musculoskeletal Science and Sports Medicine Research Centre, Department of Life Sciences, Manchester Metropolitan University, Manchester, United Kingdom

${ }^{3}$ Molecular Endocrinology Laboratory, Department of Metabolism, Digestion and Reproduction, Imperial College London, Commonwealth Building, DuCane Road, London, United Kingdom

${ }^{4}$ Institute of Orthopaedic Research and Biomechanics, University Medical Center Ulm, Ulm, Germany

${ }^{5}$ Nestlé Research, Department of Musculoskeletal Health, Innovation EPFL Park, Lausanne, Switzerland.

6 Jan van Goyen Medical Center, Department of Internal Medicine, Amsterdam, the Netherlands

${ }^{7}$ Department of Internal Medicine, Erasmus MC, University Medical Center, Rotterdam, The Netherlands

${ }^{8}$ Department of Epidemiology, Erasmus MC, University Medical Center, Rotterdam, The Netherlands

${ }^{9}$ Department of Emergency and Organ Transplantation, University of Bari, Bari, Italy

Correspondence should be addressed to E M Winter: e.m.winter@lumc.nI

\begin{abstract}
In this review we discuss skeletal adaptations to the demanding situation of pregnancy and lactation. Calcium demands are increased during pregnancy and lactation, and this is effectuated by a complex series of hormonal changes. The changes in bone structure at the tissue and whole bone level observed during pregnancy and lactation appear to largely recover over time. The magnitude of the changes observed during lactation may relate to the volume and duration of breastfeeding and return to regular menses. Studies examining long-term consequences of pregnancy and lactation suggest that there are small, site-specific benefits to bone density and that bone geometry may also be affected. Pregnancy- and lactation-induced osteoporosis (PLO) is a rare disease for which the pathophysiological mechanism is as yet incompletely known; here, we discuss and speculate on the possible roles of genetics, oxytocin, sympathetic tone and bone marrow fat. Finally, we discuss fracture healing during pregnancy and lactation and the effects of estrogen on this process.
\end{abstract}

\section{Introduction}

Pregnancy and lactation are challenging situations for the mother's skeletal homeostasis. Significant changes in maternal calcium and bone metabolism must occur to fulfill the calcium requirements to build the fetal skeleton. These processes are regulated by hormonal changes and often lead to physical changes in the mother's skeleton. In addition, lifestyle factors which have an impact on bone health can alter during pregnancy and lactation. Physical activity may be lower than usual in pregnant women, particularly in the third trimester (1), with the most marked deficits in the vigorous activities known to be beneficial to bone homeostasis. In contrast, the $10-15 \mathrm{~kg}$ weight gain during a healthy pregnancy (2) as a result of both lean and fat mass gains (3) likely increases bone and joint loading during everyday movements. While nutritional requirements are moderately increased during pregnancy (4), this appears to be counterbalanced by concurrent reductions in energy expenditure from decreased physical activity. Accordingly, there is little change in diet quality and only a small increase in energy 
intake during pregnancy and early lactation $(4,5)$ without substantial alterations in calcium intake. Despite this, the World Health Organization (WHO) recommends an extra dietary calcium intake of $200 \mathrm{mg} /$ day for pregnant women compared to non-pregnant women $(6,7)$. Here, we review the current knowledge of how the female skeleton physiologically adapts to pregnancy and lactation, how fracture healing is affected in these situations, and the pathophysiology of pregnancy- and lactation-induced osteoporosis (PLO).

\section{Physiological adaptation of bone to pregnancy and lactation}

\section{Hormonal changes during pregnancy}

During pregnancy and lactation there is an increased need for calcium in the mother to meet the fetus' calcium requirements (8). In humans, this need is met during pregnancy by increased intestinal calcium absorption and during lactation by increased calcium resorption from bone. Bone resorption is mediated by parathyroid hormone-related protein (PTHrP). PTHrP is virtually absent in the non-pregnant state and increases from the first trimester of pregnancy until labor, after which levels drop drastically within hours unless breastfeeding is initiated (9). During pregnancy, PTHrP suppresses and replaces parathyroid hormone (PTH), thereby preventing secondary and tertiary hyperparathyroidism. The first 34 amino acids of PTHrP display similarity to the structure of PTH, and therefore, PTHrP is also a ligand for the $\mathrm{PTH} / \mathrm{PTHrP}$ receptor. However, the mid- and terminal regions of PTHrP are distinct and have additional functions. The mid-molecular region stimulates placental calcium transport in the fetus (10), while the $\mathrm{COOH}$ terminal region may also inhibit osteoclast activity (11), in addition to the more generally known indirect activation of osteoclasts by production of receptor activator of nuclear factor-kappaB ligand (RANKL) in (pre) osteoblasts and osteocytes $(12,13)$. PTHrP is released from the placenta and breasts in reaction to estradiol, placental lactogen and prolactin, although other tissues including the parathyroid glands and uterus also contribute (14, $15,16)$. During pregnancy, high estradiol levels largely suppress bone resorption in response to increasing PTHrP. In early pregnancy, increased intestinal calcium absorption appears to largely satisfy fetal calcium demands, whereas higher demands during late pregnancy may additionally increase bone resorption, especially in women with calcium deficient diets (17). However, bone loss cannot be prevented by calcium supplementation (18). Estradiol levels drop during lactation. In combination with PTHrP, this drop then stimulates bone resorption $(14,15)$ in a synergistic way (19). Oxytocin also adds to this effect (see subsequently).

Physiology in pregnant and lactating humans differs from that of rodents (14). In rodents, the increase in serum calcium during lactation is not only dependent on increased bone resorption, but also on ongoing increased calcium absorption in the gastrointestinal tract mediated by increased concentrations of PTH.

PTH rises during pregnancy in rodents and the subsequent secondary hyperparathyroidism causes both augmented intestinal absorption by increased activation of cholecalciferol into calcitriol and resorption of the skeleton (14). This is in contrast to the suppression of PTH by increased PTHrP in humans. Besides PTH (rodents) and PTHrP (human), vitamin D metabolites, prolactin and placental lactogen are key regulators of calcium metabolism in mammals (14). Together they are responsible for increased calcium levels, by increasing bone resorption, stimulating intestinal calcium absorption via synthesis of calcitriol, and reducing urinary calcium waste. Calcitriol is elevated during pregnancy in both humans and rodents, and while it declines during lactation in humans, it remains elevated in rodents and stimulates intestinal calcium absorption. Calcitonin is thought to protect the skeleton from excess resorption during lactation, although few data exist for the role of calcitonin and FGF23 in this process (14).

To summarize, as already reviewed beautifully by Kovacs $(14,15)$, increased calcium needs during pregnancy are fulfilled by almost doubling intestinal calcium absorption. Meanwhile, during lactation, increased PTHrP levels act synergistically with low levels of estrogen to increase bone resorption. In rodents, increased intestinal uptake of calcium continues during lactation.

Mechanisms of pregnancy-induced bone changes are informed by the study of non-mammalian models. Birds that lay hard-shelled eggs in part fulfill their calcium requirements by resorbing calcium from medullary bone present in the marrow cavities of long bones (20). The mechanism of medullary bone turnover is identical to bone turnover in mammals. However, the process is triggered by a distinct mechanism, particularly well characterized in the seasonally reproducing Japanese quail (Coturnix coturnix japonica). Long day length triggers expression of thyroid stimulating hormone (TSH) in the pars tuberalis of the pituitary (21). This induces expression

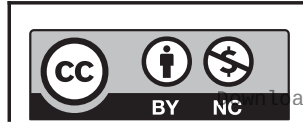

This work is licensed under a Creative Commons Attribution-NonCommercial 4.0 International License. ded from Bioscientifica.com at 04/26/2023 09:55:27AM 
of the type 2 iodothyronine deiodinase (DIO2) in the mediobasal hypothalamus (22), converting thyroxine prohormone $\left(\mathrm{T}_{4}\right)$ to bioactive 3,5,3'-triiodothyronine $\left(\mathrm{T}_{3}\right) . \mathrm{T}_{3}$ actions on gonadotrophin-releasing hormone (GnRH) nerve terminals trigger release of gonadotrophins from the pituitary, increasing gonad size and allowing reproduction. During the egg production cycle, hypocalcemia in the mother during shell calcification increases PTH levels, indirectly triggering bone resorption and providing calcium for eggshell calcification (23). Resorption of medullary bone in avian models, therefore, represents a model of rapid and pregnancy-related bone turnover.

\section{Whole-bone changes during pregnancy and lactation}

\section{Pregnancy}

The endocrine and associated metabolic changes which occur during pregnancy and lactation result in effects on the skeleton at both the microstructural and whole-bone level. At the microstructural level, results of human iliac crest bone biopsies suggest increased bone resorption in early pregnancy (8-10 weeks), whereas at term, resorption is normalised and markers of increased bone formation have been observed (24). Bone loss through trabecular thinning and reduced trabecular connectivity in early pregnancy appear to be regained through the addition of new trabeculae by late pregnancy (25). At the whole bone level, bone mineral density (BMD) assessed by clinical dual-energy X-ray absorptiometry (DXA) has been shown to decrease by up to $5 \%$ during pregnancy in the lumbar spine $(3,5,26,27,28,29)$, with several reports of smaller losses in the hip. Results at other skeletal sites are more inconsistent; these between-study discrepancies may be explained, in part, by differences in calcium intake, although variations in the timing of BMD measurement will also contribute. Quantitative CT (QCT, or pQCT for peripheral scanners) gives information on cortical and trabecular bone in addition to detailed bone geometry. However, few studies have employed these techniques to examine pregnancy-related changes, and results from the few studies available have been inconsistent. QCT/pQCT studies have found no change in cortical, trabecular or total BMD at the radius or tibia (30), distal radius cortical BMD (31) or lumbar spine trabecular BMD following pregnancy (5), respectively. In contrast, substantial variation in distal radius trabecular BMD changes between individuals were observed in one study, with annual losses of up to $21 \%$ (median $1.6 \%$ ) and with individuals with lower baseline BMD values experiencing the greatest losses (31). One recent study has examined changes in periosteal and endocortical circumferences and bone microstructure using high-resolution pQCT (HR-pQCT) to characterise the moderate and site-specific bone losses occurring during pregnancy in detail. The authors found deterioration of trabecular microarchitecture and evidence of periosteal and endocortical expansion in women aged 30-45 years across pregnancy compared to non-pregnant controls (32).

\section{Lactation}

Lactation is associated with decreases in bone mass $(33,34$, $35)$, particularly at trabecular-rich sites such as the spine and hip (33). These rates of bone loss are pronounced, with a mean $4 \%$ loss of lumbar spine BMD reported after only 3 months of feeding $(33,34,35)$. In contrast, these changes are smaller or not evident in formula-feeding mothers or non-pregnant, non-lactating women (33, 34, 35). Unfortunately, to our knowledge, no studies have used pQCT to examine changes in endocortical and periosteal geometry during lactation. Changes at the microstructural level can also be assessed in vivo using high-resolution pQCT (HR-pQCT). Longitudinal studies of breastfeeding women observed increases in cortical porosity and decreased cortical thickness, BMD and mineralisation of new bone $(36,37)$. In the same studies, trabecular number and bone volume decreased, while contrasting findings with regards to trabecular thickness were observed. The latter findings could relate to methodological issues, with trabecularisation of cortical bone influencing reported values.

Lactation-related bone losses vary substantially, with $38 \%$ of women losing $>5 \%$ spine BMD (38). Magnitude of bone loss is positively associated with the amount of breast milk produced (33). Furthermore, rates of bone microstructural change were greater during exclusive rather than intermittent feeding (36) and increased with the duration of lactation $(37,39)$. Taken together, these results suggest that increased calcium demand associated with exclusive breastfeeding or increased volume or duration of feeding results in greater bone loss. Given the modest changes in calcium intake during pregnancy and the high incidence of vitamin D insufficiency in both northern and southern latitudes in pregnant women, it could be suggested that dietary insufficiency of these nutrients would contribute to bone changes in pregnancy. However, the majority of studies suggest that vitamin D 
and calcium levels are not related $(3,33,40)$ or only weakly associated to bone turnover markers or bone loss during pregnancy and lactation (41) and that calcium supplementation has been shown to have small $(18,30)$ or transient (34) effects on bone loss in pregnancy and lactation $(42,43,44,45,46)$. Other mechanisms must thus explain these observations.

Following lactation, there appears to be full recovery and even improvements in bone mass $(34,35,47,48)$, although this appears incomplete in adolescents (49). There is some suggestion that recovery at the trabecularrich spine is quicker than in other regions. In addition, return of regular menses and use of the progestin-only contraceptive pill were associated with improved bone recovery during and after lactation $(35,48,49)$. Lactationinduced changes in bone microstructure did not resolve over a longitudinal study with median follow-up period of 3.6 years (36) such that cortical porosity was 0.6 s.D. higher and mineralisation density and trabecular number 1.3 s.D. lower in lactating women than controls. We note that this study did not control for postpartum use of hormonal birth control which may have influenced results. Overall, lactation appears to be associated with a series of changes in bone at the macro- and microstructural level. Changes at the microstructural level do not appear to be fully resolved with time, although it is unclear whether compensatory changes at the macrostructural level may preserve strength comparable to the increase in periosteal diameter in nonpregnant aging elderly with severe bone loss (50).

\section{Pregnancy in adolescence}

Another area of interest is in adolescent mothers, as it has been hypothesised that pregnancy during growth may negatively affect bone accrual. A DXA-based study (four cases, twelve matched controls) found 9-10\% lower total body and hip BMD (51) in late adolescent mothers at follow-up at 19-21 years of age, although lactation was not controlled for. A pQCT-based study found a $1 \%$ decrease in radius cortical $\mathrm{BMD}$ and a $4 \%$ decrease in total body BMC in new teenage mothers (mean age 18 years) (52), although both studies were limited by small numbers of participants. However, these studies focused on later adolescent mothers where pregnancy occurs after peak growth, and this limited the understanding of the effects of early post-pubertal pregnancies. One study which did examine earlier pregnancies found impaired recovery of post-weaning lumbar spine and total body BMD in mothers aged 14 and 15 years compared to those aged 16 or 17 years (53).

\section{Long-term effects of pregnancy and lactation}

The long-term effects of pregnancy and lactation on bone characteristics in later life have also been examined, and overall small, site-specific benefits to BMD have been observed (54). While no strong evidence for differences in BMD was observed between paired parous/nulliparous twins, in a large cross-sectional study, parity was associated with both greater lumbar spine BMD and total body BMC than in other female relatives, while breastfeeding was associated with higher total body BMC and hip BMD (55). No association between gravidity, parity and BMD was observed in women aged 40-80 years, but parity was associated with greater total body and femoral neck bone area (56). Similarly, cumulative duration of lactation was associated with increased femoral neck and tibia bone cross sectional area (CSA) in women 16-20 years after their final pregnancy (57). Therefore, longerterm effects of pregnancy may primarily relate to altered size rather than density (56). These associations appear site specific, as gravidity and parity were not associated with vertebral shape or size at age 46 in a Finnish cohort (58). This may relate to the suppression of estrogens (which inhibit periosteal apposition) during lactation, with similar expansion of the axial skeleton observed in both eumenorrheic and amenorrheic athletes with lower estrogen levels (59). The long-term effects of adolescent pregnancy are unclear, having been associated with higher BMD $(60,61)$ and lower BMD at multiple sites (62). In terms of long-term clinical consequences, parity and lactation were not found to be associated with increased fracture risk over a 16-year follow-up (63).

\section{Pathophysiology during pregnancy and lactation}

As described in the 'Whole-bone changes during pregnancy and lactation' section, it is known that bone loss during pregnancy and lactation is a result of the hormonal changes that are made to fulfill the increased calcium requirements for fetal and neonatal development $(14,64,65)$. If intestinal calcium absorption is insufficient to meet calcium demands, calcium is mobilized from the maternal skeleton by either osteoclast activity or osteocytic osteolysis mechanisms $(14,66)$, which in turn cause a decrease in bone mass. It is not yet understood why some mothers exhibit pregnancy- and lactationassociated osteoporosis (PLO) and fracture while others do not, despite both having low vitamin $\mathrm{D}$ and low estrogen status (65). Moreover, at pre-clinical levels, it has been shown that maximizing calcium and vitamin $\mathrm{D}$

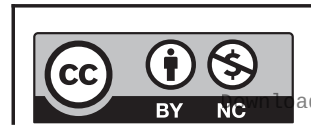


physiology through calcitriol supplementation is not sufficient to restore specific bone loss during pregnancy and lactation $(42,43,44,46)$. More recently, it has been shown that calcium restriction during this period has minimal effects on post-weaning bone metabolic changes (45). These studies may explain why some clinical trials failed to demonstrate a full prevention of bone loss during pregnancy and lactation with calcium supplementation $(18,67)$. Since it has not been demonstrated that differences in inactivity levels can explain PLO, and since pathologically raised PTHrP levels are rare (16), other factors including genetic polymorphisms, sympathetic nervous system activity, secretion of oxytocin, and bone marrow fat may contribute to bone loss and disturbance of microarchitecture during pregnancy and lactation (summarized in Fig. 1). This may explain some of the differences between physiological and pathophysiological bone loss, that is, PLO. We will discuss each of these subsequently.

\section{Genetics}

Early reports have indicated that hereditary factors may play a role in PLO. Osteoporotic fractures at younger age more often have a genetic cause $(68,69)$, in contrast to osteoporotic fractures at older ages which are often due to simple postmenopausal osteoporosis. Remarkably, a high prevalence of fractures has been reported in cases of mothers with PLO (70). Other findings included lack of recovery of bone density in the mother during years of follow-up after delivery and osteopenia in the children when screened at a young age (71). Finally, a series of five index cases with PLO patients revealed osteoporosis, as defined by low BMD, in over half of their relatives (72).

Multiple cases have been published which describe patients in whom a genetic cause of PLO has been identified. Osteogenesis imperfecta is the best-known form of monogenic osteoporosis, and indeed, heterozygous COL1A1 or COL1A2 mutations have been found in several cases of PLO $(73,74)$. These autosomal dominant mutations lead to qualitative or quantitative defects in the formation of collagen type I (75). Other cases have been attributed to mutations in the gene encoding the LRP5 (low-density lipoprotein receptor-related protein (75) cell-surface protein receptor, a key player in intracellular signaling pathways including the Wnt pathway (74). Simple and compound heterozygous LRP5 mutations have been described in PLO specifically $(74,76)$.

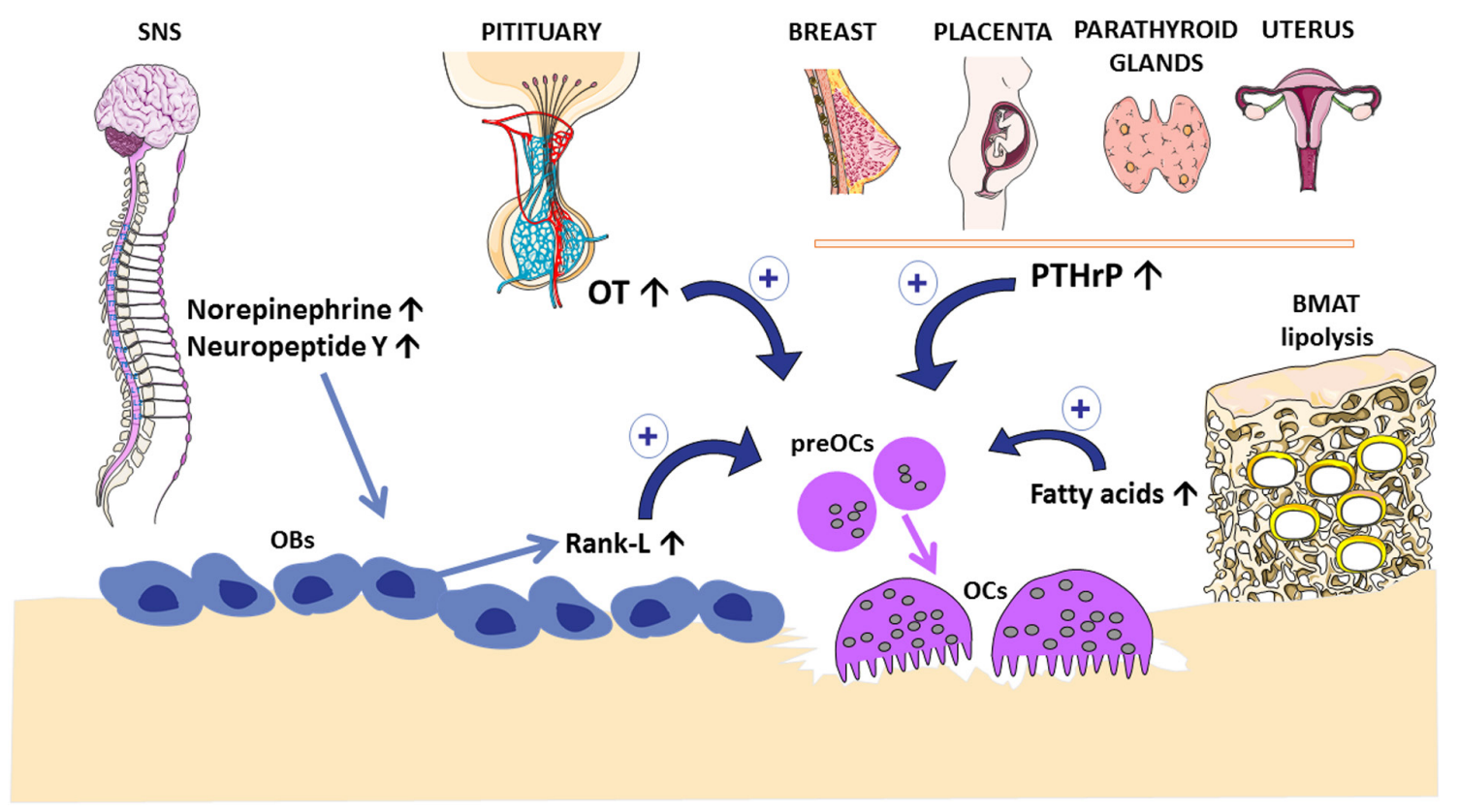

Figure 1

Proposed model for the control of osteoclastogenesis and resorptive function of osteoclast (OCs) during adaptations of the skeleton to the demanding situations of pregnancy and lactation. Parathyroid hormone-related protein (PTHrP), synthesized in the placenta, breast tissue, parathyroid glands and the uterus, is the main actor of increased bone resorption. The increased production of oxytocin (OT) from the posterior pituitary stimulates osteoclastogenesis by acting on the osteoclast precursor (preOCs). The over-activity of the sympathetic nervous system (SNS), which increases release of neurotransmitters such as norepinephrine, stimulates bone resorption through an enhanced RANKL secretion by osteoblasts (OBs). In the bone marrow adipose tissue (BMAT), adipocytes undergo lipolysis to provide fatty acids as an energy source for the increased bone resorption.

https://ec.bioscientifica.com https://doi.org/10.1530/EC-20-0055 (c) 2020 The authors Published by Bioscientifica Ltd

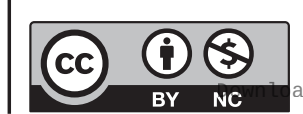

This work is licensed under a Creative Commons Attribution-NonCommercial 4.0 International License. ded from Bioscientifica.com at 04/26/2023 09:55:27AM 
Osteoporosis may be associated with visual impairments, such as osteoporosis pseudoglioma syndrome/familial exudative vitreoretinopathy, in these patients. This is because LRP5 has been shown to be essential for the development of blood vessels in the eye (77) as well as bone accrual. The underlying genetic mechanisms may be more complex in some patients, as illustrated by the report of a patient with a heterozygous LRP5 mutation together with homozygous polymorphisms in the MTHFR gene encoding methylenetetrahydrofolate reductase, an enzyme involved in homocysteine metabolism (78). Intriguingly, osteoporosis did not cosegregate in this patient's family with the LRP5 mutation, the homozygous MTHFR polymorphism, or even the combination of the two, implicating additional genetic or non-genetic factors in PLO.

Consideration of a genetic cause for PLO is recommended for patients with a family history of osteoporosis and fragility fractures or a severe phenotype such as a history of fractures before pregnancy and severely reduced BMD (Z-score < -2.0 s.D.). This is especially critical in cases in which BMD does not recover in the months after pregnancy and/or weaning (79). Screening for an underlying monogenetic bone disorder has been further proposed in patients in whom PLO occurs together with one of the following features: joint hypermobility and blue sclerae (indicative of osteogenesis imperfecta), congenital blindness, or severely reduced vision (as associated with osteoporosis pseudoglioma syndrome). Nowadays, genetic diagnostics are often offered in multi-gene test panels labeled 'osteogenesis imperfecta and related conditions' which may include additional variants derived from familial osteoporosis, osteogenesis imperfecta, and genome-wide association studies, studies $(80,81,82)$. The indication for genetic testing should be seriously considered, because a diagnosis has significant implications for the patient as well as their relatives. Similar to the systematic genetic studies performed for BMD and fractures in general, there is a need for genomewide association studies for PLO $(83,84,85,86)$.

\section{Oxytocin}

Plasma levels of oxytocin peak during late pregnancy and lactation. These periods coincide with rapid fetal skeletogenesis and neonatal bone modelling, both processes that require a high intake of calcium ions for mineralization, which is delivered by the mother (87). Oxytocin originated as a highly conserved nanopeptide for electrolytic homeostasis in primitive vertebrates over
400 million years ago (88). Although it is well known that oxytocin facilitates parturition, this hormone is not indispensable for this function (89). In fact, oxytocin knock-out mice $\left(O T^{-/}\right)$can give birth normally but are unable to feed their pups because of the lack of milk ejection reflex. This defect is completely reversible by peripheral injection of oxytocin, suggesting that its primary role in mammalian lactation is mediated by a peripheral action rather than a central mechanism (89). Conversely, the regulation of maternal and sexual behavior, social memory, and penile erection and ejaculation in males are mediated by a central action of oxytocin $(90,91,92,93)$.

In addition to its action on social behavior, milk ejection, and uterine contraction, receptors for oxytocin are expressed on osteoblasts, osteoclasts, and their precursors $(94,95)$. Furthermore, bone marrow osteoblasts synthesize oxytocin, suggesting the existence of an oxytocin/oxytocin receptor system in the bone milieu regulated by autocrine and paracrine interactions $(95,96)$. Oxytocin stimulates osteoblast differentiation (97), and $O T^{-/-}$mice as well as mice lacking the oxytocin receptor $\left(O T R^{-/}\right)$display reduced bone mass, mainly due to a bone-forming defect (95). Systemic injections of oxytocin into WT rodents increase bone mass and improve osseointegration of titanium implants $(98,99)$. At the same time, oxytocin stimulates differentiation of pre-osteoclastas (Fig. 1) by increasing the ratio of RANKL and osteoprotegerin (OPG), while inhibiting bone resorption by triggering cytosolic $\mathrm{Ca}^{2+}$ release and nitric oxide synthesis. More specifically, oxytocin increases the expression of the $\mathrm{Ca}^{2+}$ sensitive NOS isoform (eNOS) and triggers a time-dependent increase in the production of nitric oxide, as a mechanism to inhibit bone resorption (95). Altogether these results are consistent with the hypothesis that oxytocin is responsible for maintaining a high rate of cell activity in bone, stimulating the proliferation of both forming and resorbing cells, while at the same time controlling the amount of bone resorbed. The inhibitory effect of oxytocin on mature osteoclasts may serve as a checkpoint for bone resorption that would otherwise be unrestricted following stimulation of osteoclastogenesis.

PTHrP, indispensable for the development of the mammary gland and pro-resorptive during breastfeeding (100), is only partly responsible for the intergenerational calcium transfer. It has been suggested that this complex process, fundamental for skeletal morphogenesis, is also driven by oxytocin. The anabolic effect of oxytocin may facilitate the restoration of the maternal skeleton, while its pro-osteoclastogenic action may contribute to the 
intergenerational transfer of calcium. As evidence of this, pregnant $O T^{-/-}$mice have reduced markers of bone formation and $\mathrm{OT}^{-/-}$pups displayed hypo-mineralized skeletons (101). Furthermore, pregnant WT mice exhibited increased plasma levels of C-telopeptide, a marker of bone resorption, and osteoclast cultures obtained from the bone marrow of these mice showed higher numbers of TRAP-positive cells than non-pregnant mice (101). Intraperitoneal injections of oxytocin thrice weekly for 5 weeks in non-pregnant mice, as well as the addition of oxytocin to bone marrow cell cultures obtained from control mice, mimicked this pregnancy-induced increase in osteoclastogenesis (101). A similar result has been obtained in 12 healthy women with spontaneous vaginal deliveries at term. The number and size of osteoclasts generated in vitro from peripheral blood of these women were significantly higher than age-matched controls (102).

Overall, these findings show that the enhanced osteoclast formation can be explained by elevated oxytocin levels during late pregnancy (103). Consistent with this hypothesis, pregnant mice lacking oxytocin showed a $\sim 80 \%$ reduction in ex vivo osteoclast formation compared with WT pregnant littermates, suggesting that the osteoclastogenesis triggered in pregnant mice is, at least in part, dependent upon an intact oxytocin axis. It is therefore possible that the increase in serum oxytocin levels during pregnancy is responsible for the increase in osteoclast formation which tends to mobilize maternal calcium for fetal skeletogenesis to occur. Additionally, considering that oxytocin mainly stimulates osteoblastogenesis (95), it has been investigated whether osteoblast formation $e x$ vivo was enhanced in pregnant WT mice and whether this response was reduced in oxytocin-deficiency. As expected, the formation of alkaline phosphatase-positive colonies (CFU-f) was increased during pregnancy in mice, as mimicked by intraperitoneal oxytocin injection, thrice weekly, in non-pregnant mice, indicating that oxytocin might be responsible for inducing osteoblast formation (101). The uncoupling of bone remodeling from net skeletal loss during lactation has been mainly ascribed to decreased levels of estrogen (100). However, estrogen deficiency during menopause causes irreversible bone loss, while PLO is mostly reversible in both rodents and humans (104). Nevertheless, maternal bone loss would be continuous in the absence of a mechanism that would inhibit excessive osteoclastic resorption. Therefore, it has been proposed that oxytocin, which also inhibits resorption by mature osteoclasts (95), provides one of these mechanisms for the self-regulation of oxytocininduced osteoclastogenesis and bone loss. Overall, these studies indicate that oxytocin, which is also a mammary gland-specific peptide (89), is important for the regulation of intergenerational calcium transfer and is possibly also mechanistically involved in PLO in humans.

\section{Sympathetic nervous system}

Genetically and pharmacologically induced overactivity of the sympathetic nervous system (SNS) has been well demonstrated to be deleterious for bone mass and structure $(105,106,107,108)$. This is explained by an increase in bone resorption through enhanced activating transcription factor 4(ATF4)/RANKL secretion by osteoblasts (109), in combination with decreased osteoblastogenesis (105). In line with this, a recent randomized clinical trial demonstrated that patients treated with $\beta$-adrenoreceptor-selective blockers had better bone microarchitecture than nonusers (110). It has been demonstrated that SNS activity is important for regulation of pregnancy and lactation $(111,112)$, but to our knowledge, the direct contribution of the SNS to PLO has never been investigated or reported.

During pregnancy (113), the increase in neural activity is likely to manifest as an increase in the release of neurotransmitters such as norepinephrine (NE) and neuropeptide $Y(114,115)$, resulting in an early increase in blood pressure within the first few weeks of conception $(116,117)$. Since both neurotransmitters are linked to bone metabolism $(118,119,120)$, we speculate that they could be involved in PLO, although this has not been studied to date. During lactation, levels of both NE and serotonin (5-hydroxytryptamine, 5HT) in the anterior cerebral cortex, hippocampus, and cerebellum have been shown to increase, particularly from late pregnancy to early postpartum period, and continue to increase in the postpartum period (121). This implicates NE and serotonin in the regulation of hormone secretion and bone metabolism changes during these periods. The increased SNS activity during lactation is magnified during postpartum depression, which occurs in $25-35 \%$ of pregnant women after delivery (122). Interestingly, a connection between depression, bone loss and SNS activity increase has been demonstrated (123). Moreover, modulation of the SNS could also control other tissues such as adipose tissue (124) which is well known to be associated with bone remodeling levels $(125,126)$. However, as stated, the role of SNS in PLO remains highly speculative. 


\section{Bone marrow fat}

Bone marrow adipocytes appear in the bone marrow directly after birth and continue to expand throughout the skeleton during growth. In humans, at the age of 25 years, most of the marrow of the long bones is occupied by adipocytes, whereas in the axial skeleton the marrow remains mostly hematopoietic. However, bone marrow adipocytes accumulate with aging, and there is a clear inverse association between bone marrow adiposity and bone mass, which is accentuated in diseases characterized by increased fracture risk such as osteoporosis. This is hypothesised to be due to a shift in the lineage allocation of the skeletal stem cell, favoring adipogenesis over osteoblastogenesis. However, situations of 'beneficial' increased bone marrow adiposity have also been described, such as hematopoietic regeneration following radiation or chemotherapy. In this situation, bone marrow adipocytes are hypothesised to be a source of energy by supplying fatty acids to hematopoietic and bone cells (127).

Studies of bone marrow adiposity during pregnancy and lactation have not been performed in humans. In rats, bone marrow adipocytes, as assessed by histomorphometry of the vertebrae, decrease both in number and volume during and after pregnancy, in lactating and non-lactating mothers, compared to nonpregnant controls (128). The changes in bone marrow adipocytes were negatively correlated with changes in bone formation parameters, although the decrease in bone marrow adiposity was accompanied by a decrease in bone volume. In mice, bone marrow adiposity, as assessed by osmium staining of the tibia, also decreases significantly during lactation and this was accompanied by a decrease in trabecular bone volume (129). These two studies show that bone marrow adiposity decreases during pregnancy and lactation and that this is accompanied by a decrease in bone volume. A possible hypothesis is that the bone marrow adipocytes undergo lipolysis to provide fatty acids as an energy source for the increased bone resorption due to the increased calcium demands both for fetal skeletal development and for maternal milk production. Interestingly, the disappearance of adipocytes during lactation has also been described in the mammary gland of mice (130). Mammary adipocytes were shown to undergo de-differentiation during lactation and re-differentiation during weaning. Whether bone marrow adipocytes could also undergo this de- and re-differentiation remains to be investigated.

\section{PLO profile and treatment}

PLO is rare, and its prevalence is unknown. The occurrence of fragility fractures appears mostly in the third trimester and lactation period (131), typically presenting in the first pregnancy with acute back pain from (multiple) vertebral fragility fractures and subsequently determined low BMD. Since premenopausal women rarely undergo DXA scanning, the pre-pregnancy BMD in these women is mostly unknown. Bone loss, predominantly from trabecular bone sites, in combination with the increased weight bearing and the lordotic posture of pregnancy, is assumed to lead to these spontaneous vertebral fractures. Decreased BMD prior to pregnancy in such premenopausal women is mostly caused by osteoporosis secondary to anorexia nervosa, endocrine diseases (e.g. Cushing's disease, hyperthyroidism or primary hyperparathyroidism), inflammatory diseases (e.g. rheumatoid arthritis or inflammatory bowel diseases) or medication (e.g. glucocorticoids or cancer treatments) (15).

Vertebral fractures presenting with back pain should be treated with appropriate pain medication and advice on weight bearing and mobility. Quality of life and capacity to work should also be taken into account, although long-term prognosis for PLO is good (132). In general, pharmacological treatment for low bone mass is not indicated, except calcium and vitamin D supplements, since bone mass recovers fully in the year following weaning and the onset of the menstrual cycle (3). Several studies have shown that parity and lactation are not associated with increased long-term risk of postmenopausal osteoporosis and fractures and that they may even protect against hip fractures $(133,134)$. Moreover, PLO typically presents in first pregnancy, with limited evidence for increased fracture risk in future pregnancies $(17,135)$. In contrast, Kyvernitakis et al. have shown that the refracture risk in subsequent pregnancies is $20 \%$ and that the refracture rate after 6 years is $25 \%$, with risk positively related to the number of fractures during the pregnancy (136). Therefore, it remains important to counsel women with PLO on the fracture risk associated with lactation and further pregnancies. Treatment with anti-osteoporosis medication such as the anti-resorptive bisphosphonates, the anabolic PTH anaologue teriparatide, and the human monoclonal RANKL antibody denosumab has been shown to be effective in increasing BMD, although there are no data on fracture outcomes and the reported studies did not include a placebo-treated control (17).
This work is licensed under a Creative Commons Attribution-NonCommercial 4.0 International License. ded from Bioscientifica.com at 04/26/2023 09:55:27AM 
In addition, the possible fracture reduction following treatment with bisphosphonates that are retained in the bone (137) should be weighed against a possible negative effect on skeletal development of the fetus in following pregnancies and other pregnancy-related complications such as low birth weight. Although the limited available evidence in humans has not indicated that bisphosphonate treatment causes major congenital anomalies, the number of patients exposed is not sufficient to draw any conclusions on the safety profile of these medications (138). Moreover, use of teriparatide and denosumab are contraindicated during pregnancy and lactation and should therefore be used with caution in patient groups of fertile age.

\section{Fracture healing during pregnancy}

Although severe fractures are rather rare during pregnancy, several clinical case reports have described fracture healing during pregnancy $(139,140,141,142)$. These studies suggest that fracture healing is accelerated during pregnancy, based on earlier bone bridging of the fracture callus and reduced time until bony union. This appears to be independent from the stage of pregnancy at which the fracture occurred. Accelerated bone regeneration may be due to the positive impact of several pregnancyassociated growth factors (such as pregnancy-associated plasma protein-A and placental growth factor) on fracture healing, which was demonstrated in experimental studies $(143,144)$. Increased estrogen levels may also account for improved bone regeneration, as estrogen application was shown to accelerate fracture healing (145). In line with this, several experimental studies in rodent models of estrogen-deficiency demonstrated delayed fracture healing. Ovariectomised (OVX), estrogen-deficient rats and mice displayed decreased mechanical properties and bone formation in the late fracture callus $(146,147,148)$. The number of osteoclasts was significantly increased during callus development (149). This might be explained by the effects of estrogen in increasing osteoclast and decreasing osteoblast apoptosis $(150,151,152)$ and by stimulating the recruitment, proliferation and differentiation of skeletal progenitor cells $(153,154)$. Analysis of the intermediate phase of endochondral fracture healing in OVX mice further demonstrated a decreased cartilaginous callus area (145) and a reduced expression of cartilage markers (155) and angiogenic factors (156). Therefore, bone regeneration appears to be disturbed by estrogen deficiency both during the middle and late phases of healing, with changes in angiogenesis and the formation of the cartilaginous and the bony callus. The molecular mechanisms underlying these findings remain unclear. However, as it is known that postmenopausal females display a chronic lowgrade inflammatory phenotype and the inflammatory response to injury is altered under estrogen-deficiency (157, 158, 159), estrogen may also modulate the inflammatory response after fracture. Indeed, recent studies demonstrated an imbalanced immune response to fracture in OVX mice and postmenopausal fracture patients $(160,161)$. In particular, the molecule midkine (Mdk) appears to play an important role in this process. Mdk is known to be both a proinflammatory cytokine regulated by estrogen (162) and a negative regulator of bone formation (163) and fracture healing (164). Indeed, antibody inhibition of Mdk reduced the negative effects of serum from postmenopausal fracture patients on the osteogenic differentiation of human MSCs. Overall, accelerated fractured healing during pregnancy might be due to the positive effects of increased estrogen levels on bony and cartilaginous callus formation as well as on the inflammatory response after fracture.

\section{Conclusion}

Reproduction brings about changes in the endocrinemediated processes of calcium, mineral and bone metabolism. This applies to pregnancy in humans and other mammals, as there is a need for building material for the fetal skeleton. Moreover, physical changes occuring in pregnant and lactating women such as excessive weight on the lumbar spine region cause physiological and pathophysiological changes which are not yet fully elucidated. We have discussed the possible contribution of oxytocin, genetics, bone marrow fat and the SNS to pathophysiological changes such as PLO. Finally, fracture healing appears to be improved during pregnancy, and this is possibly due to the positive effects of estrogen on bone regeneration.

\section{Declaration of interest}

The authors declare that there is no conflict of interest that could be perceived as prejudicing the impartiality of this review.

\section{Funding}

This work did not receive any specific grant from any funding agency in the public, commercial, or not-for-profit sector.
This work is licensed under a Creative Commons Attribution-NonCommercial 4.0 International License. ded from Bioscientifica.com at 04/26/2023 09:55:27AM via free access 


\section{Acknowledgements}

The authors thank Servier Medical Art (https://smart.servier.com/) for providing free image software to build the figure.

\section{References}

1 Evenson KR \& Wen F. Prevalence and correlates of objectively measured physical activity and sedentary behavior among US pregnant women. Preventive Medicine 201153 39-43. (https://doi. org/10.1016/j.ypmed.2011.04.014)

2 Rasmussen KM, Catalano PM \& Yaktine AL. New guidelines for weight gain during pregnancy: what obstetrician/gynecologists should know. Current Opinion in Obstetrics \& Gynecology 200921 521-526. (https://doi.org/10.1097/GCO.0b013e328332d24e)

3 Møller UK, Við Streym S, Mosekilde L \& Rejnmark L. Changes in bone mineral density and body composition during pregnancy and postpartum. A controlled cohort study. Osteoporosis International 2012 23 1213-1223. (https://doi.org/10.1007/s00198-011-1654-6)

4 van Raaij JM, Vermaat-Miedema SH, Schonk CM, Peek ME \& Hautvast JG. Energy requirements of pregnancy in the Netherlands. Lancet 19872 953-955. (https://doi.org/10.1016/s01406736(87)91431-0)

5 Ritchie LD, Fung EB, Halloran BP, Turnlund JR, Van Loan MD, Cann CE \& King JC. A longitudinal study of calcium homeostasis during human pregnancy and lactation and after resumption of menses. American Journal of Clinical Nutrition 199867 693-701. (https://doi.org/10.1093/ajcn/67.4.693)

6 World Health Organization. Guideline: Calcium Supplementation in Pregnant Women. Geneva, Switzerland: WHO, 2013. (available at: https://www.who.int/nutrition/publications/micronutrients/ guidelines/calcium_supplementation/en/)

7 Food and Agriculture Organization of the United Nations, World Health Organization. Human Vitamin and Mineral Requirements, Rome, Italy: FAO, 2001. (available at: http://www.fao.org/3/a-y2809e.pdf)

8 Kovacs CS \& Kronenberg HM. Maternal-fetal calcium and bone metabolism during pregnancy, puerperium, and lactation. Endocrine Reviews 199718 832-872. (https://doi.org/10.1210/edrv.18.6.0319)

9 Ardawi MS, Nasrat HA \& BA'Aqueel HS. Calcium-regulating hormones and parathyroid hormone-related peptide in normal human pregnancy and postpartum: a longitudinal study. European Journal of Endocrinology 1997137 402-409. (https://doi.org/10.1530/ eje.0.1370402)

10 Kovacs CS, Lanske B, Hunzelman JL, Guo J, Karaplis AC \& Kronenberg HM. Parathyroid hormone-related peptide (PTHrP) regulates fetal-placental calcium transport through a receptor distinct from the PTH/PTHrP receptor. PNAS 199693 15233-15238. (https:// doi.org/10.1073/pnas.93.26.15233)

11 Cornish J, Callon KE, Nicholson GC \& Reid IR. Parathyroid hormone-related protein-(107-139) inhibits bone resorption in vivo. Endocrinology 1997138 1299-1304. (https://doi.org/10.1210/ endo.138.3.4990)

12 Martin TJ. Osteoblast-derived PTHrP is a physiological regulator of bone formation. Journal of Clinical Investigation 2005115 2322-2324. (https://doi.org/10.1172/JCI26239)

13 Nakashima T, Hayashi M, Fukunaga T, Kurata K, Oh-Hora M, Feng JQ, Bonewald LF, Kodama T, Wutz A, Wagner EF, et al. Evidence for osteocyte regulation of bone homeostasis through RANKL expression. Nature Medicine 201117 1231-1234. (https://doi. org/10.1038/nm.2452)

14 Kovacs CS. Maternal mineral and bone metabolism: during pregnancy, lactation, and post-weaning recovery. Physiological Reviews 201696 449-547. (https://doi.org/10.1152/ physrev.00027.2015)
15 Kovacs CS. Osteoporosis presenting in pregnancy, puerperium, and lactation. Current Opinion in Endocrinology, Diabetes, and Obesity 2014 21 468-475. (https://doi.org/10.1097/MED.0000000000000102)

16 Winter EM \& Appelman-Dijkstra NM. Parathyroid hormone-related protein-induced hypercalcemia of pregnancy successfully reversed by a dopamine agonist. Journal of Clinical Endocrinology \& Metabolism 2017102 4417-4420. (https://doi.org/10.1210/jc.2017-01617)

17 Kovacs CS \& Ralston SH. Presentation and management of osteoporosis presenting in association with pregnancy or lactation. Osteoporosis International 201526 2223-2241. (https://doi. org/10.1007/s00198-015-3149-3)

18 Kalkwarf HJ, Specker BL, Bianchi DC, Ranz J \& Ho M. The effect of calcium supplementation on bone density during lactation and after weaning. New England Journal of Medicine 1997337 523-528. (https://doi.org/10.1056/NEJM199708213370803)

19 Masiukiewicz US, Mitnick M, Gulanski BI \& Insogna KL. Evidence that the IL-6/IL-6 soluble receptor cytokine system plays a role in the increased skeletal sensitivity to PTH in estrogen-deficient women. Journal of Clinical Endocrinology \& Metabolism 200287 2892-2898. (https://doi.org/10.1210/jcem.87.6.8577)

20 Whitehead CC. Overview of bone biology in the egg-laying hen. Poultry Science 200483 193-199. (https://doi.org/10.1093/ ps/83.2.193)

21 Nakao N, Ono H, Yamamura T, Anraku T, Takagi T, Higashi K, Yasuo S, Katou Y, Kageyama S, Uno Y, et al. Thyrotrophin in the pars tuberalis triggers photoperiodic response. Nature $2008 \mathbf{4 5 2} 317-322$. (https://doi.org/10.1038/nature06738)

22 Yoshimura T, Yasuo S, Watanabe M, Iigo M, Yamamura T, Hirunagi K \& Ebihara S. Light-induced hormone conversion of T4 to T3 regulates photoperiodic response of gonads in birds. Nature $2003 \mathbf{4 2 6}$ 178-181. (https://doi.org/10.1038/nature02117)

23 Taylor TG \& Belanger LF. The mechanism of bone resorption in laying hens. Calcified Tissue Research 19694 162-173. (https://doi. org/10.1007/BF02279117)

24 Purdie DW, Aaron JE \& Selby PL. Bone histology and mineral homeostasis in human pregnancy. British Journal of Obstetrics \& Gynaecology 198895 849-854. (https://doi. org/10.1111/j.1471-0528.1988.tb06568.x)

25 Shahtaheri SM, Aaron JE, Johnson DR \& Purdie DW. Changes in trabecular bone architecture in women during pregnancy. British Journal of Obstetrics \& Gynaecology 1999106 432-438. (https://doi. org/10.1111/j.1471-0528.1999.tb08296.x)

26 Naylor KE, Iqbal P, Fledelius C, Fraser RB \& Eastell R. The effect of pregnancy on bone density and bone turnover. Journal of Bone and Mineral Research 200015 129-137. (https://doi.org/10.1359/ jbmr.2000.15.1.129)

27 Black AJ, Topping J, Durham B, Farquharson RG \& Fraser WD. A detailed assessment of alterations in bone turnover, calcium homeostasis, and bone density in normal pregnancy. Journal of Bone and Mineral Research 200015 557-563. (https://doi.org/10.1359/ jbmr.2000.15.3.557)

28 Ulrich U, Miller PB, Eyre DR, Chesnut CH, Schlebusch H \& Soules MR. Bone remodeling and bone mineral density during pregnancy. Archives of Gynecology \& Obstetrics 2003268 309-316. (https://doi.org/10.1007/s00404-002-0410-8)

29 Kaur M, Pearson D, Godber I, Lawson N, Baker P \& Hosking D. Longitudinal changes in bone mineral density during normal pregnancy. Bone 200332 449-454. (https://doi.org/10.1016/s87563282(03)00017-6)

30 Cullers A, King JC, Van Loan M, Gildengorin G \& Fung EB. Effect of prenatal calcium supplementation on bone during pregnancy and 1 y postpartum. American Journal of Clinical Nutrition 2019109 197-206. (https://doi.org/10.1093/ajcn/nqy233)

31 Wisser J, Florio I, Neff M, König V, Huch R, Huch A \& von Mandach U. Changes in bone density and metabolism in pregnancy. https://ec.bioscientifica.com https://doi.org/10.1530/EC-20-0055 (c) 2020 The authors Published by Bioscientifica Ltd

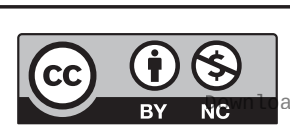

This work is licensed under a Creative Commons Attribution-NonCommercial 4.0 International License. ded from Bioscientifica.com at 04/26/2023 09:55:27AM 
Acta Obstetricia \& Gynecologica Scandinavica 200584 349-354 (https://doi.org/10.1111/j.0001-6349.2005.00766.x)

32 Ó Breasail M, Prentice A \& Ward K. Pregnancy-related bone mineral and microarchitecture changes in women aged 30 to 45 years. Journal of Bone and Mineral Research 2020 [epub]. (https://doi.org/10.1002/ jbmr.3998)

33 Laskey MA, Prentice A, Hanratty LA, Jarjou LM, Dibba B, Beavan SR $\&$ Cole TJ. Bone changes after 3 mo of lactation: influence of calcium intake, breast-milk output, and vitamin D-receptor genotype. American Journal of Clinical Nutrition 199867 685-692. (https://doi. org/10.1093/ajcn/67.4.685)

34 Polatti F, Capuzzo E, Viazzo F, Colleoni R \& Klersy C. Bone mineral changes during and after lactation. Obstetrics \& Gynecology 199994 52-56. (https://doi.org/10.1016/s0029-7844(99)00236-7)

35 Kalkwarf HJ \& Specker BL. Bone mineral loss during lactation and recovery after weaning. Obstetrics \& Gynecology 199586 26-32. (https://doi.org/10.1016/0029-7844(95)00083-4)

36 Bjørnerem Å, Ghasem-Zadeh A, Wang X, Bui M, Walker SP, Zebaze R $\&$ Seeman E. Irreversible deterioration of cortical and trabecular microstructure associated With breastfeeding. Journal of Bone and Mineral Research 201732 681-687. (https://doi.org/10.1002/jbmr.3018)

37 Brembeck P, Lorentzon M, Ohlsson C, Winkvist A \& Augustin H. Changes in cortical volumetric bone mineral density and thickness, and trabecular thickness in lactating women postpartum. Journal of Clinical Endocrinology \& Metabolism 2015100 535-543. (https://doi. org/10.1210/jc.2014-2825)

38 Pearson D, Kaur M, San P, Lawson N, Baker P \& Hosking D. Recovery of pregnancy mediated bone loss during lactation. Bone 200434 570-578. (https://doi.org/10.1016/j.bone.2003.11.005)

39 More C, Bettembuk P, Bhattoa HP \& Balogh A. The effects of pregnancy and lactation on bone mineral density. Osteoporosis International 200112 732-737. (https://doi.org/10.1007/ s001980170048)

40 Sowers M, Zhang D, Hollis BW, Shapiro B, Janney CA, Crutchfield M, Schork MA, Stanczyk F \& Randolph J. Role of calciotrophic hormones in calcium mobilization of lactation. American Journal of Clinical Nutrition 199867 284-291. (https://doi.org/10.1093/ ajcn/67.2.284)

41 O'Brien KO, Nathanson MS, Mancini J \& Witter FR. Calcium absorption is significantly higher in adolescents during pregnancy than in the early postpartum period. American Journal of Clinical Nutrition 200378 1188-1193. (https://doi.org/10.1093/ ajcn/78.6.1188)

42 Fudge NJ \& Kovacs CS. Pregnancy up-regulates intestinal calcium absorption and skeletal mineralization independently of the vitamin D receptor. Endocrinology 2010151 886-895. (https://doi. org/10.1210/en.2009-1010)

43 Korecki CL, Zinser G, Liu X, Siedler J, Welsh J \& Niebur GL. Effect of the vitamin $\mathrm{D}$ receptor on bone geometry and strength during gestation and lactation in mice. Calcified Tissue International $2009 \mathbf{8 5}$ 405-411. (https://doi.org/10.1007/s00223-009-9281-3)

44 Gillies BR, Ryan BA, Tonkin BA, Poulton IJ, Ma Y, Kirby BJ, St-Arnaud R, Sims NA \& Kovacs CS. Absence of calcitriol causes increased lactational bone loss and lower milk calcium but does not impair post-lactation bone recovery in Cyp27b1 null mice. Journal of Bone and Mineral Research 201833 16-26. (https://doi.org/10.1002/ jbmr.3217)

45 Ross RD, Meagher MJ \& Sumner DR. Calcium restriction during lactation has minimal effects on post-weaning mineral metabolism and bone recovery. Journal of Bone \& Mineral Metabolism 201937 648-657. (https://doi.org/10.1007/s00774-018-0969-1)

46 Miller SC, Halloran BP, DeLuca HF \& Jee WS. Role of vitamin D in maternal skeletal changes during pregnancy and lactation: a histomorphometric study. Calcified Tissue International 198234 245-252. (https://doi.org/10.1007/BF02411245)
47 Laskey MA \& Prentice A. Bone mineral changes during and after lactation. Obstetrics \& Gynecology 199994 608-615. (https://doi. org/10.1016/s0029-7844(99)00369-5)

48 Cooke-Hubley S, Kirby BJ, Valcour JE, Mugford G, Adachi JD \& Kovacs CS. Spine bone mineral density increases after 6 months of exclusive lactation, even in women who keep breastfeeding. Archives of Osteoporosis 201712 73. (https://doi.org/10.1007/s11657-0170368-6)

49 Bezerra FF, Mendonça LM, Lobato EC, O’Brien KO \& Donangelo CM. Bone mass is recovered from lactation to postweaning in adolescent mothers with low calcium intakes. American Journal of Clinical Nutrition 200480 1322-1326. (https://doi.org/10.1093/ ajcn/80.5.1322)

50 Seeman E. Periosteal bone formation - a neglected determinant of bone strength. New England Journal of Medicine 2003349 320-323. (https://doi.org/10.1056/NEJMp038101)

51 Lloyd T, Lin HM, Eggli DF, Dodson WC, Demers LM \& Legro RS. Adolescent Caucasian mothers have reduced adult hip bone density. Fertility \& Sterility 200277 136-140. (https://doi.org/10.1016/s00150282(01)02924-7)

52 Ward KA, Adams JE, Roberts SA, Mughal Z \& Seif MW. Postpartum bone status in teenage mothers assessed using peripheral quantitative computed tomography. Journal of Clinical Densitometry 200912 219-223. (https://doi.org/10.1016/j.jocd.2009.01.001)

53 Malpeli A, Mansur JL, De Santiago S, Villalobos R, Armanini A, Apezteguía M \& González HF. Changes in bone mineral density of adolescent mothers during the 12-month postpartum period. Public Health Nutrition 201013 1522-1527. (https://doi.org/10.1017/ S1368980009992199)

54 Song SY, Kim Y, Park H, Kim YJ, Kang W \& Kim EY. Effect of parity on bone mineral density: a systematic review and meta-analysis. Bone 2017101 70-76. (https://doi.org/10.1016/j.bone.2017.04.013)

55 Paton LM, Alexander JL, Nowson CA, Margerison C, Frame MG, Kaymakci B \& Wark JD. Pregnancy and lactation have no long-term deleterious effect on measures of bone mineral in healthy women: a twin study. American Journal of Clinical Nutrition 2003 77 707-714. (https://doi.org/10.1093/ajcn/77.3.707)

56 Specker B \& Binkley T. High parity is associated with increased bone size and strength. Osteoporosis International 200516 1969-1974. (https://doi.org/10.1007/s00198-005-1978-1)

57 Wiklund PK, Xu L, Wang Q, Mikkola T, Lyytikäinen A, Völgyi E, Munukka E, Cheng SM, Alen M, Keinänen-Kiukaanniemi S, et al. Lactation is associated with greater maternal bone size and bone strength later in life. Osteoporosis International 201223 1939-1945. (https://doi.org/10.1007/s00198-011-1790-z)

58 Oura P, Paananen M, Auvinen J, Niinimäki J, Niinimäki M, Karppinen J \& Junno JA. Gravidity, parity, and vertebral dimensions in the northern Finland birth cohort 1966. Spine 201843 E1102-E1108. (https://doi.org/10.1097/BRS.0000000000002640)

59 Piasecki J, Ireland A, Piasecki M, Cameron J, McPhee JS \& Degens H. The strength of weight-bearing bones is similar in amenorrheic and eumenorrheic elite long-distance runners. Scandinavian Journal of Medicine \& Science in Sports 201828 1559-1568. (https://doi. org/10.1111/sms.13062)

60 Yüce T, Kalafat E \& Koc A. Adolescent pregnancy; a determinant of bone mineral density in peri-menopausal women? Maturitas 201582 203-207. (https://doi.org/10.1016/j.maturitas.2015.07.007)

61 Chantry CJ, Auinger P \& Byrd RS. Lactation among adolescent mothers and subsequent bone mineral density. Archives of Pediatrics \& Adolescent Medicine 2004158 650-656. (https://doi.org/10.1001/ archpedi.158.7.650)

62 Cho GJ, Shin JH, Yi KW, Park HT, Kim T, Hur JY \& Kim SH. Adolescent pregnancy is associated with osteoporosis in postmenopausal women. Menopause 201219 456-460. (https://doi. org/10.1097/gme.0b013e3182337150) https://ec.bioscientifica.com https://doi.org/10.1530/EC-20-0055
This work is licensed under a Creative Commons Attribution-NonCommercial 4.0 International License. ed from Bioscientifica com at 04/26/2023 09:55:27AM 
63 Cooke-Hubley S, Gao Z, Mugford G, Kaiser SM, Goltzman D, Leslie WD, Davison KS, Brown JP, Probyn L, Lentle B, et al. Parity and lactation are not associated with incident fragility fractures or radiographic vertebral fractures over 16 years of follow-up: Canadian Multicentre Osteoporosis Study (CaMos). Archives of Osteoporosis 201914 49. (https://doi.org/10.1007/s11657-019-0601-6)

64 Eisman J. Relevance of pregnancy and lactation to osteoporosis? Lancet 1998352 504-505. (https://doi.org/10.1016/S01406736(05)79245-X)

65 Miyamoto T, Miyakoshi K, Sato Y, Kasuga Y, Ikenoue S, Miyamoto K, Nishiwaki Y, Tanaka M, Nakamura M \& Matsumoto M. Changes in bone metabolic profile associated with pregnancy or lactation. Scientific Reports 20199 6787. (https://doi.org/10.1038/s41598-01943049-1)

66 Wein MN. Parathyroid hormone signaling in osteocytes. JBMR Plus 20182 22-30. (https://doi.org/10.1002/jbm4.10021)

67 Prentice A, Jarjou LM, Cole TJ, Stirling DM, Dibba B \& FairweatherTait S. Calcium requirements of lactating Gambian mothers: effects of a calcium supplement on breast-milk calcium concentration, maternal bone mineral content, and urinary calcium excretion. American Journal of Clinical Nutrition 199562 58-67. (https://doi org/10.1093/ajcn/62.1.58)

68 Michaelsson K, Melhus H, Ferm H, Ahlbom A \& Pedersen NL. Genetic liability to fractures in the elderly. Archives of Internal Medicine 2005165 1825-1830. (https://doi.org/10.1001/ archinte.165.16.1825)

69 Koromani F, Trajanoska K, Rivadeneira F \& Oei L. Recent advances in the genetics of fractures in osteoporosis. Frontiers in Endocrinology 201910 337. (https://doi.org/10.3389/fendo.2019.00337)

70 Dunne F, Walters B, Marshall T \& Heath DA. Pregnancy associated osteoporosis. Clinical Endocrinology 199339 487-490. (https://doi. org/10.1111/j.1365-2265.1993.tb02398.x)

71 Carbone LD, Palmieri GM, Graves SC \& Smull K. Osteoporosis of pregnancy: long-term follow-up of patients and their offspring. Obstetrics \& Gynecology 199586 664-666. (https://doi. org/10.1016/0029-7844(95)00226-h)

72 Peris P, Guanabens N, Monegal A, Pons F, Martinez de Osaba MJ, Ros I \& Munoz-Gomez J. Pregnancy associated osteoporosis: the familial effect. Clinical \& Experimental Rheumatology 200220 697-700.

73 Pabinger C, Heu C, Frohner A \& Dimai HP. Pregnancy- and lactationassociated transient osteoporosis of both hips in a 32 year old patient with osteogenesis imperfecta. Bone 201251 142-144. (https://doi. org/10.1016/j.bone.2012.04.013)

74 Butscheidt S, Delsmann A, Rolvien T, Barvencik F, Al-Bughaili M, Mundlos S, Schinke T, Amling M, Kornak U \& Oheim R. Mutational analysis uncovers monogenic bone disorders in women with pregnancy-associated osteoporosis: three novel mutations in LRP5, COL1A1, and COL1A2. Osteoporosis International 201829 1643-1651. (https://doi.org/10.1007/s00198-018-4499-4)

75 Basel D \& Steiner RD. Osteogenesis imperfecta: recent findings shed new light on this once well-understood condition. Genetics in Medicine 200911 375-385. (https://doi.org/10.1097/ GIM.0b013e3181a1ff7b)

76 Campos-Obando N, Oei L, Hoefsloot LH, Kiewiet RM, Klaver CC, Simon ME \& Zillikens MC. Osteoporotic vertebral fractures during pregnancy: be aware of a potential underlying genetic cause. Journal of Clinical Endocrinology \& Metabolism 201499 1107-1111. (https:// doi.org/10.1210/jc.2013-3238)

77 Jiao X, Ventruto V, Trese MT, Shastry BS \& Hejtmancik JF. Autosomal recessive familial exudative vitreoretinopathy is associated with mutations in LRP5. American Journal of Human Genetics 200475 878-884. (https://doi.org/10.1086/425080)

78 Cook FJ, Mumm S, Whyte MP \& Wenkert D. Pregnancyassociated osteoporosis with a heterozygous deactivating LDL receptor-related protein 5 (LRP5) mutation and a homozygous methylenetetrahydrofolate reductase (MTHFR) polymorphism Journal of Bone and Mineral Research 201429 922-928. (https://doi. org/10.1002/jbmr.2095)

79 Campos-Obando N, Oei L, Hoefsloot LH, Kiewiet RM, Klaver CC, Simon ME \& Zillikens MC. Osteoporotic vertebral fractures during pregnancy: be aware of a potential underlying genetic cause. Journal of Clinical Endocrinology \& Metabolism 201499 1107-1111. (https:// doi.org/10.1210/jc.2013-3238)

80 Collet C, Ostertag A, Ricquebourg M, Delecourt M, Tueur G, Isidor B, Guillot P, Schaefer E, Javier RM, Funck-Brentano T, et al. Primary osteoporosis in Young adults: genetic basis and identification of novel variants in causal genes. JBMR Plus 20182 12-21. (https://doi. org/10.1002/jbm4.10020)

81 Weiss MM, Van der Zwaag B, Jongbloed JD, Vogel MJ, Brüggenwirth HT, Lekanne Deprez RH, Mook O, Ruivenkamp CA, van Slegtenhorst MA, van den Wijngaard A, et al. Best practice guidelines for the use of next-generation sequencing applications in genome diagnostics: a national collaborative study of Dutch genome diagnostic laboratories. Human Mutation 201334 1313-1321. (https://doi.org/10.1002/humu.22368)

82 Mäkitie RE, Costantini A, Kämpe A, Alm JJ \& Mäkitie O. New insights into monogenic causes of osteoporosis. Frontiers in Endocrinology 201910 70. (https://doi.org/10.3389/fendo.2019.00070)

83 Estrada K, Styrkarsdottir U, Evangelou E, Hsu YH, Duncan EL, Ntzani EE, Oei L, Albagha OM, Amin N, Kemp JP, et al. Genome-wide meta-analysis identifies 56 bone mineral density loci and reveals 14 loci associated with risk of fracture. Nature Genetics $2012 \mathbf{4 4} 491-501$. (https://doi.org/10.1038/ng.2249)

84 Nielson CM, Liu CT, Smith AV, Ackert-Bicknell CL, Reppe S, Jakobsdottir J, Wassel C, Register TC, Oei L, Alonso N, et al. Novel genetic variants associated With increased vertebral volumetric BMD, reduced vertebral fracture risk, and increased expression of SLC1A3 and EPHB2. Journal of Bone and Mineral Research 201631 2085-2097. (https://doi.org/10.1002/jbmr.2913)

85 Zheng HF, Forgetta V, Hsu YH, Estrada K, Rosello-Diez A, Leo PJ, Dahia CL, Park-Min KH, Tobias JH, Kooperberg C, et al. Wholegenome sequencing identifies EN1 as a determinant of bone density and fracture. Nature 2015526 112-117. (https://doi.org/10.1038/ nature14878)

86 Kemp JP, Medina-Gomez C, Estrada K, St Pourcain B, Heppe DH, Warrington NM, Oei L, Ring SM, Kruithof CJ, Timpson NJ, et al. Phenotypic dissection of bone mineral density reveals skeletal site specificity and facilitates the identification of novel loci in the genetic regulation of bone mass attainment. PLOS Genetics 201410 e1004423. (https://doi.org/10.1371/journal.pgen.1004423)

87 Wysolmerski JJ. The evolutionary origins of maternal calcium and bone metabolism during lactation. Journal of Mammary Gland Biology \& Neoplasia 20027 267-276. (https://doi. org/10.1023/a:1022800716196)

88 Acher R, Chauvet J, Chauvet MT, Michel G \& Rouillé Y. Molecular evolution of neurohypophysial hormones in relation to osmoregulation: the two fish options. Fish Physiology and Biochemistry 199717 325-332. (https://doi.org/10.1023/A:1007720909113)

89 Nishimori K, Young LJ, Guo Q, Wang Z, Insel TR \& Matzuk MM. Oxytocin is required for nursing but is not essential for parturition or reproductive behavior. PNAS 199693 11699-11704. (https://doi. org/10.1073/pnas.93.21.11699)

90 Young WS, Shepard E, DeVries AC, Zimmer A, LaMarca ME, Ginns EI, Amico J, Nelson RJ, Hennighausen L \& Wagner KU. Targeted reduction of oxytocin expression provides insights into its physiological roles. Advances in Experimental Medicine \& Biology 1998 449 231-240. (https://doi.org/10.1007/978-1-4615-4871-3_30)

91 Insel TR \& Harbaugh CR. Lesions of the hypothalamic paraventricular nucleus disrupt the initiation of maternal behavior. Physiology \& Behavior 198945 1033-1041. (https://doi. org/10.1016/0031-9384(89)90234-5)

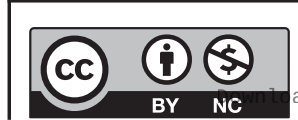


92 Mantella RC, Vollmer RR, Li X \& Amico JA. Female oxytocindeficient mice display enhanced anxiety-related behavior. Endocrinology 2003144 2291-2296. (https://doi.org/10.1210/ en.2002-0197)

93 Argiolas A, Collu M, Gessa GL, Melis MR \& Serra G. The oxytocin antagonist d(CH2)5Tyr(Me)-Orn8-vasotocin inhibits male copulatory behaviour in rats. European Journal of Pharmacology 1988149 389-392. (https://doi.org/10.1016/0014-2999(88)90675-9)

94 Colucci S, Colaianni G, Mori G, Grano M \& Zallone A. Human osteoclasts express oxytocin receptor. Biochemical \& Biophysical Research Communications 2002297 442-445. (https://doi. org/10.1016/s0006-291x(02)02009-0)

95 Tamma R, Colaianni G, Zhu LL, DiBenedetto A, Greco G, Montemurro G, Patano N, Strippoli M, Vergari R, Mancini Le, et al. Oxytocin is an anabolic bone hormone. PNAS 2009106 7149-7154. (https://doi.org/10.1073/pnas.0901890106)

96 Colaianni G, Di Benedetto A, Zhu LL, Tamma R, Li J, Greco G, Peng Y, Dell'Endice S, Zhu G, Cuscito C, et al. Regulated production of the pituitary hormone oxytocin from murine and human osteoblasts. Biochemical \& Biophysical Research Communications 2011 411 512-515. (https://doi.org/10.1016/j.bbrc.2011.06.158)

97 Elabd C, Basillais A, Beaupied H, Breuil V, Wagner N, Scheideler M, Zaragosi LE, Massiéra F, Lemichez E, Trajanoski Z, et al. Oxytocin controls differentiation of human mesenchymal stem cells and reverses osteoporosis. Stem Cells 200826 2399-2407. (https://doi. org/10.1634/stemcells.2008-0127)

98 Elabd SK, Sabry I, Hassan WB, Nour H \& Zaky K. Possible neuroendocrine role for oxytocin in bone remodeling. Endocrine Regulations 200741 131-141.

99 Wang M, Lan L, Li T, Li J \& Li Y. The effect of oxytocin on osseointegration of titanium implant in ovariectomized rats. Connective Tissue Research 201657 220-225. (https://doi.org/10.3109 /03008207.2016.1141902)

100 VanHouten JN, Dann P, Stewart AF, Watson CJ, Pollak M, Karaplis AC \& Wysolmerski JJ. Mammary-specific deletion of parathyroid hormone-related protein preserves bone mass during lactation. Journal of Clinical Investigation 2003112 1429-1436. (https://doi. org/10.1172/JCI19504)

101 Liu X, Shimono K, Zhu LL, Li J, Peng Y, Imam A, Iqbal J, Moonga S, Colaianni G, Su C, et al. Oxytocin deficiency impairs maternal skeletal remodeling. Biochemical \& Biophysical Research Communications 2009388 161-166. (https://doi.org/10.1016/j. bbrc.2009.07.148)

102 Patano N, Marinaccio M, Vimercati A, Camerino C, Mancini L, Selvaggi L \& Zallone A. Enhanced osteoclastogenesis in women after natural delivery. Biochemical \& Biophysical Research Communications 2005334 487-490. (https://doi.org/10.1016/j.bbrc.2005.06.126)

103 Dawood MY, Ylikorkala O, Trivedi D \& Fuchs F. Oxytocin in maternal circulation and amniotic fluid during pregnancy. Journal of Clinical Endocrinology \& Metabolism 197949 429-434. (https://doi. org/10.1210/jcem-49-3-429)

104 Kovacs CS \& Fulehan GH. Calcium and bone disorders during pregnancy and lactation. Endocrinology \& Metabolism 200635 21-51, v.

105 Takeda S, Elefteriou F, Levasseur R, Liu X, Zhao L, Parker KL, Armstrong D, Ducy P \& Karsenty G. Leptin regulates bone formation via the sympathetic nervous system. Cell 2002111 305-317. (https:// doi.org/10.1016/s0092-8674(02)01049-8)

106 Elefteriou F, Ahn JD, Takeda S, Starbuck M, Yang X, Liu X, Kondo H, Richards WG, Bannon TW, Noda M, et al. Leptin regulation of bone resorption by the sympathetic nervous system and CART. Nature 2005434 514-520. (https://doi.org/10.1038/nature03398)

107 Bonnet N, Beaupied H, Vico L, Dolleans E, Laroche N, Courteix D $\&$ Benhamou CL. Combined effects of exercise and propranolol on bone tissue in ovariectomized rats. Journal of Bone and Mineral Research 200722 578-588. (https://doi.org/10.1359/jbmr.070117)
108 Bonnet N, Benhamou CL, Malaval L, Goncalves C, Vico L, Eder V, Pichon C \& Courteix D. Low dose beta-blocker prevents ovariectomy-induced bone loss in rats without affecting heart functions. Journal of Cellular Physiology 2008217 819-827. (https:// doi.org/10.1002/jcp.21564)

109 Baek K, Park HJ, Baek JH \& Kim HR. Isoproterenol increases RANKL expression in a ATF4/NFATc1-dependent manner in mouse osteoblastic cells. International Journal of Molecular Sciences 201718. (https://doi.org/10.3390/ijms18102204)

110 Khosla S, Drake MT, Volkman TL, Thicke BS, Achenbach SJ, Atkinson EJ, Joyner MJ, Rosen CJ, Monroe DG \& Farr JN. Sympathetic $\beta 1$-adrenergic signaling contributes to regulation of human bone metabolism. Journal of Clinical Investigation 2018128 4832-4842. (https://doi.org/10.1172/JCI122151)

111 Greengrass PM \& Tonge SR. The concentrations of the monoamines and their precursor amino acids in three areas of mouse brain during pregnancy. Archives Internationales de Pharmacodynamie \& de Therapie $197421075-84$.

112 Greengrass PM \& Tonge SR. The accumulation of noradrenaline and 5-hydroxytryptamine in three regions of mouse brain after tetrabenazine and iproniazid: effects of ethinyloestradiol and progesterone. Psychopharmacologia 197439 187-191. (https://doi. org/10.1007/BF00440848)

113 Reyes LM, Usselman CW, Davenport MH \& Steinback CD. Sympathetic nervous system regulation in human normotensive and hypertensive pregnancies. Hypertension 201871 793-803. (https:// doi.org/10.1161/HYPERTENSIONAHA.117.10766)

114 Macarthur H, Wilken GH, Westfall TC \& Kolo LL. Neuronal and nonneuronal modulation of sympathetic neurovascular transmission. Acta Physiologica 2011203 37-45. (https://doi.org/10.1111/j.17481716.2010.02242.x)

115 Pablo Huidobro-Toro J \& Verónica Donoso M. Sympathetic co-transmission: the coordinated action of ATP and noradrenaline and their modulation by neuropeptide $\mathrm{Y}$ in human vascular neuroeffector junctions. European Journal of Pharmacology $2004 \mathbf{5 0 0}$ 27-35. (https://doi.org/10.1016/j.ejphar.2004.07.008)

116 Barron WM, Mujais SK, Zinaman M, Bravo EL \& Lindheimer MD. Plasma catecholamine responses to physiologic stimuli in normal human pregnancy. American Journal of Obstetrics \& Gynecology 1986 154 80-84. (https://doi.org/10.1016/0002-9378(86)90397-2)

117 Jarvis SS, Shibata S, Bivens TB, Okada Y, Casey BM, Levine BD \& $\mathrm{Fu}$ Q. Sympathetic activation during early pregnancy in humans. Journal of Physiology 2012590 3535-3543. (https://doi.org/10.1113/ jphysiol.2012.228262)

118 Baldock PA, Lee NJ, Driessler F, Lin S, Allison S, Stehrer B, Lin EJ, Zhang L, Enriquez RF, Wong IP, et al. Neuropeptide Y knockout mice reveal a central role of NPY in the coordination of bone mass to body weight. PLoS One 20094 e8415. (https://doi.org/10.1371/journal. pone.0008415)

119 Elefteriou F. Regulation of bone remodeling by the central and peripheral nervous system. Archives of Biochemistry \& Biophysics 2008 473 231-236. (https://doi.org/10.1016/j.abb.2008.03.016)

120 Baldock PA, Lin S, Zhang L, Karl T, Shi Y, Driessler F, Zengin A, Hörmer B, Lee NJ, Wong IP, et al. Neuropeptide y attenuates stressinduced bone loss through suppression of noradrenaline circuits. Journal of Bone and Mineral Research 201429 2238-2249. (https://doi. org/10.1002/jbmr.2205)

121 Desan PH, Woodmansee WW, Ryan SM, Smock TK \& Maier SF. Monoamine neurotransmitters and metabolites during the estrous cycle, pregnancy, and the postpartum period. Pharmacology, Biochemistry, \& Behavior 198830 563-568. (https://doi. org/10.1016/0091-3057(88)90066-4)

122 Henshaw C. Mood disturbance in the early puerperium: a review. Archives of Women's Mental Health 20036 (Supplement 2) S33-S42. (https://doi.org/10.1007/s00737-003-0004-x) https://ec.bioscientifica.com https://doi.org/10.1530/EC-20-0055 (c) 2020 The authors Published by Bioscientifica Ltd

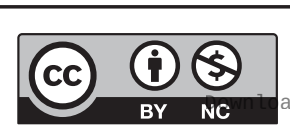

This work is licensed under a Creative Commons Attribution-NonCommercial 4.0 International License. ded from Bioscientifica.com at 04/26/2023 09:55:27AM 
123 Yirmiya R, Goshen I, Bajayo A, Kreisel T, Feldman S, Tam J, Trembovler V, Csernus V, Shohami E \& Bab I. Depression induces bone loss through stimulation of the sympathetic nervous system. PNAS 2006103 16876-16881. (https://doi.org/10.1073/ pnas.0604234103)

124 McNamara JP \& Murray CE. Sympathetic nervous system activity in adipose tissues during pregnancy and lactation of the rat. Journal of Dairy Science 200184 1382-1389. (https://doi.org/10.3168/jds.S00220302(01)70169-5)

125 Bermeo S, Gunaratnam K \& Duque G. Fat and bone interactions. Current Osteoporosis Reports 201412 235-242. (https://doi. org/10.1007/s11914-014-0199-y)

126 Muruganandan S, Govindarajan R \& Sinal CJ. Bone marrow adipose tissue and skeletal health. Current Osteoporosis Reports 201816 434-442. (https://doi.org/10.1007/s11914-018-0451-y)

127 Veldhuis-Vlug AG \& Rosen CJ. Mechanisms of marrow adiposity and its implications for skeletal health. Metabolism: Clinical and Experimental 201767 106-114. (https://doi.org/10.1016/j. metabol.2016.11.013)

128 Honda A, Kurabayashi T, Yahata T, Tomita M, Matsushita H, Takakuwa K \& Tanaka K. Effects of pregnancy and lactation on trabecular bone and marrow adipocytes in rats. Calcified Tissue International 200067 367-372. (https://doi.org/10.1007/ s002230001145)

129 Bornstein S, Brown SA, Le PT, Wang X, DeMambro V, Horowitz MC, MacDougald O, Baron R, Lotinun S, Karsenty G, et al. FGF-21 and skeletal remodeling during and after lactation in C57BL/6J mice. Endocrinology 2014155 3516-3526. (https://doi.org/10.1210/ en.2014-1083)

130 Wang QA, Song A, Chen W, Schwalie PC, Zhang F, Vishvanath L, Jiang L, Ye R, Shao M, Tao C, et al. Reversible de-differentiation of mature white adipocytes into preadipocyte-like precursors during lactation. Cell Metabolism 201828 282-288.e3. (https://doi. org/10.1016/j.cmet.2018.05.022)

131 Hadji P, Boekhoff J, Hahn M, Hellmeyer L, Hars O \& Kyvernitakis I. Pregnancy-associated osteoporosis: a case-control study. Osteoporosis International 201728 1393-1399. (https://doi.org/10.1007/s00198016-3897-8)

132 Gehlen M, Lazarescu AD, Hinz C, Schwarz-Eywill M, Pfeifer M, Balasingam S \& Maier A. Long-term outcome of patients with pregnancy and lactation-associated osteoporosis (PLO) with a particular focus on quality of life. Clinical Rheumatology 201938 3575-3583. (https://doi.org/10.1007/s10067-019-04758-0)

133 Bjørnerem A, Ahmed LA, Jørgensen L, Størmer J \& Joakimsen RM. Breastfeeding protects against hip fracture in postmenopausal women: the Tromsø study. Journal of Bone and Mineral Research 2011 26 2843-2850. (https://doi.org/10.1002/jbmr.496)

134 Sowers M. Pregnancy and lactation as risk factors for subsequent bone loss and osteoporosis. Journal of Bone and Mineral Research 1996 11 1052-1060. (https://doi.org/10.1002/jbmr.5650110803)

135 Phillips AJ, Ostlere SJ \& Smith R. Pregnancy-associated osteoporosis: does the skeleton recover? Osteoporosis International 200011 449-454. (https://doi.org/10.1007/s001980070113)

136 Kyvernitakis I, Reuter TC, Hellmeyer L, Hars O \& Hadji P. Subsequent fracture risk of women with pregnancy and lactation-associated osteoporosis after a median of 6 years of follow-up. Osteoporosis International 201829 135-142. (https://doi.org/10.1007/s00198-0174239-1)

137 Papapoulos SE \& Cremers SC. Prolonged bisphosphonate release after treatment in children. New England Journal of Medicine 2007356 1075-1076. (https://doi.org/10.1056/NEJMc062792)

138 Sokal A, Elefant E, Leturcq T, Beghin D, Mariette X \& Seror R. Pregnancy and newborn outcomes after exposure to bisphosphonates: a case-control study. Osteoporosis International 2019 30 221-229. (https://doi.org/10.1007/s00198-018-4672-9)
139 Kozbagarov AA. Process of fracture consolidation in females during pregnancy and lactation. Ortopediia Travmatologiia i Protezirovanie 197132 24-28.

140 Coulson S, Palacios T \& Vitetta L. Perna canaliculus (Green-lipped mussel): bioactive components and therapeutic evaluation for chronic health conditions. Progress in Drug Research 201570 91-132. (https://doi.org/10.1007/978-3-0348-0927-6_3)

141 Ahmad MA, Kuhanendran D, Kamande IW \& Charalambides C. Accelerated tibial fracture union in the third trimester of pregnancy: a case report. Journal of Medical Case Reports 20082 44. (https://doi. org/10.1186/1752-1947-2-44)

142 Neumann C, Asbach P, Fuechtmeier B, Maghsudi M \& Nerlich M. Surgical treatment of an acetabular fracture during pregnancy. Der Unfallchirurg 2003106 419-423. (https://doi.org/10.1007/s00113003-0585-x)

143 Miller BS, Bronk JT, Nishiyama T, Yamagiwa H, Srivastava A, Bolander ME \& Conover CA. Pregnancy associated plasma protein-A is necessary for expeditious fracture healing in mice. Journal of Endocrinology 2007192 505-513. (https://doi.org/10.1677/JOE-06-0011)

144 Maes C, Coenegrachts L, Stockmans I, Daci E, Luttun A, Petryk A, Gopalakrishnan R, Moermans K, Smets N, Verfaillie CM, et al. Placental growth factor mediates mesenchymal cell development, cartilage turnover, and bone remodeling during fracture repair. Journal of Clinical Investigation 2006116 1230-1242. (https://doi. org/10.1172/JCI26772)

145 Beil FT, Barvencik F, Gebauer M, Seitz S, Rueger JM, Ignatius A, Pogoda P, Schinke T \& Amling M. Effects of estrogen on fracture healing in mice. Journal of Trauma 201069 1259-1265. (https://doi. org/10.1097/TA.0b013e3181c4544d)

146 Namkung-Matthai H, Appleyard R, Jansen J, Hao Lin J, Maastricht S, Swain M, Mason RS, Murrell GA, Diwan AD \& Diamond T. Osteoporosis influences the early period of fracture healing in a rat osteoporotic model. Bone 200128 80-86. (https://doi.org/10.1016/ s8756-3282(00)00414-2)

147 Meyer RA Jr, Tsahakis PJ, Martin DF, Banks DM, Harrow ME \& Kiebzak GM. Age and ovariectomy impair both the normalization of mechanical properties and the accretion of mineral by the fracture callus in rats. Journal of Orthopaedic Research 200119 428-435. (https://doi.org/10.1016/S0736-0266(00)90034-2)

148 Hao YJ, Zhang G, Wang YS, Qin L, Hung WY, Leung K \& Pei FX. Changes of microstructure and mineralized tissue in the middle and late phase of osteoporotic fracture healing in rats. Bone $2007 \mathbf{4 1}$ 631-638. (https://doi.org/10.1016/j.bone.2007.06.006)

149 Islam AA, Rasubala L, Yoshikawa H, Shiratsuchi Y \& Ohishi M. Healing of fractures in osteoporotic rat mandible shown by the expression of bone morphogenetic protein-2 and tumour necrosis factor-alpha. British Journal of Oral \& Maxillofacial Surgery 200543 383-391. (https://doi.org/10.1016/j.bjoms.2004.10.018)

150 Nakamura T, Imai Y, Matsumoto T, Sato S, Takeuchi K, Igarashi K, Harada Y, Azuma Y, Krust A, Yamamoto Y, et al. Estrogen prevents bone loss via estrogen receptor alpha and induction of Fas ligand in osteoclasts. Cell 2007130 811-823. (https://doi.org/10.1016/j. cell.2007.07.025)

151 Kousteni S, Bellido T, Plotkin LI, O’Brien CA, Bodenner DL, Han L, Han K, DiGregorio GB, Katzenellenbogen JA, Katzenellenbogen BS, et al. Nongenotropic, sex-nonspecific signaling through the estrogen or androgen receptors: dissociation from transcriptional activity. Cell 2001104 719-730.

152 Yang YH, Chen K, Li B, Chen JW, Zheng XF, Wang YR, Jiang SD \& Jiang LS. Estradiol inhibits osteoblast apoptosis via promotion of autophagy through the ER-ERK-mTOR pathway. Apoptosis 201318 1363-1375. (https://doi.org/10.1007/s10495-013-0867-x)

153 Cheung WY, Fritton JC, Morgan SA, Seref-Ferlengez Z, Basta-Pljakic J, Thi MM, Suadicani SO, Spray DC, Majeska RJ \& Schaffler MB. Pannexin-1 and P2X7-receptor are required for apoptotic osteocytes https://ec.bioscientifica.com https://doi.org/10.1530/EC-20-0055 (c) 2020 The authors Published by Bioscientifica Ltd

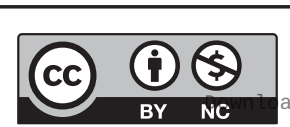

This work is licensed under a Creative Commons Attribution-NonCommercial 4.0 International License. ded from Bioscientifica.com at 04/26/2023 09:55:27AM 
in fatigued bone to trigger RANKL production in neighboring bystander osteocytes. Journal of Bone and Mineral Research 201631 890-899. (https://doi.org/10.1002/jbmr.2740)

154 Shang ZZ, Li X, Sun HQ, Xiao GN, Wang CW \& Gong Q.

Differentially expressed genes and signalling pathways are involved in mouse osteoblast-like MC3T3-E1 cells exposed to 17-beta estradiol. International Journal of Oral Science 20146 142-149. (https://doi. org/10.1038/ijos.2014.2)

155 Hatano H, Siegel HJ, Yamagiwa H, Bronk JT, Turner RT, Bolander ME \& Sarkar G. Identification of estrogen-regulated genes during fracture healing, using DNA microarray. Journal of Bone \& Mineral Metabolism 200422 224-235. (https://doi.org/10.1007/s00774-0030482-y)

156 Li W, Wang K, Liu Z \& Ding W. HIF-1alpha change in serum and callus during fracture healing in ovariectomized mice. International Journal of Clinical \& Experimental Pathology 20158 117-126.

157 Ginaldi L, De Martinis M, Ciccarelli F, Saitta S, Imbesi S, Mannucci C \& Gangemi S. Increased levels of interleukin 31 (IL-31) in osteoporosis. BMC Immunology 2015 16 60. (https://doi.org/10.1186/ s12865-015-0125-9)

158 Ginaldi L, Di Benedetto MC \& De Martinis M. Osteoporosis, inflammation and ageing. Immunity \& Ageing 20052 14. (https://doi. org/10.1186/1742-4933-2-14)

159 Routley CE \& Ashcroft GS. Effect of estrogen and progesterone on macrophage activation during wound healing. Wound Repair and Regeneration 200917 42-50. (https://doi.org/10.1111/j.1524475X.2008.00440.x)

160 Haffner-Luntzer M, Fischer V, Prystaz K, Liedert A \& Ignatius A. The inflammatory phase of fracture healing is influenced by oestrogen status in mice. European Journal of Medical Research 20172223. (https://doi.org/10.1186/s40001-017-0264-y)

161 Fischer V, Kalbitz M, Muller-Graf F, Gebhard F, Ignatius A, Liedert A $\&$ Haffner-Luntzer M. Influence of menopause on inflammatory cytokines during murine and human bone fracture healing. International Journal of Molecular Sciences 2018 19. (https://doi. org/10.3390/ijms19072070)

162 Diamond-Stanic MK, Romero-Aleshire MJ, Hoyer PB, Greer K, Hoying JB \& Brooks HL. Midkine, a heparin-binding protein, is increased in the diabetic mouse kidney postmenopause. American Journal of Physiology. Renal Physiology 2011300 F139-F146. (https:// doi.org/10.1152/ajprenal.00249.2010)

163 Liedert A, Mattausch L, Rontgen V, Blakytny R, Vogele D, Pahl M, Bindl R, Neunaber C, Schinke T, Harroch S, et al. Midkine-deficiency increases the anabolic response of cortical bone to mechanical loading. Bone 201148 945-951. (https://doi.org/10.1016/j.bone.2010.12.019)

164 Haffner-Luntzer M, Heilmann A, Rapp AE, Roessler R, Schinke T, Amling M, Ignatius A \& Liedert A. Antagonizing midkine accelerates fracture healing in mice by enhanced bone formation in the fracture callus. British Journal of Pharmacology 2016173 2237-2249. (https:// doi.org/10.1111/bph.13503)

Received in final form 23 April 2020

Accepted 12 May 2020

Accepted Manuscript published online 12 May 2020
This work is licensed under a Creative Commons Attribution-NonCommercial 4.0 International License. ded from Bioscientifica.com at 04/26/2023 09:55:27AM 